\title{
Gender perspective in the news of rape on Harian Haluan
}

\author{
Hendrika Era Farida ${ }^{1}$, Novia Juita ${ }^{2}$, Ngusman Abdul Manaf ${ }^{3}$ \\ ${ }^{123}$ Universitas Negeri Padang, Padang - Indonesia, (hendrika.zai@gmail.com)
}

\begin{abstract}
Coverage on certain mass media allegedly marginalizes women victims of rape. The purpose of this study was to to describe the gender perspective in the news of rape on the Harian Haluan. This writing analyzes reports of rape in the mass media using the method of critical discourse analysis model Sara Mills. The results showed (1) the position of women in the news of rape on the dominant Harian Haluan as the object of telling and (2) the gender ideology in the news of rape on Harian Haluan is patriarchy ideology. Most of the news of rape contains the assumption that men have power over women so women tend to be inferior and subordinated. Furthermore, the alignment of journalists in the news of rape on Harian Haluan, it was concluded that journalists tend to side with the perpetrators of rape.
\end{abstract}

Keywords: gender perspective, news of rape, harian haluan

\section{Introduction}

The mass media has contributed to the movement of gender. Mass media is used as a forum for women's negotiations and a place to debate critical discourse containing pros and cons on gender. The phenomenon of mass media often raises the theme of the struggle of a woman, the injustice experienced by women and so on. However, the media often meet the theme of women who actually contain discrimination, cornering, and looking at women as someone who is always under the authority of men. Mass media usually presents information into news form. Preaching of violence against women, especially rape.

The rise of cases of rape that occurred this, make the media aggressively preach about it. In addition, research on violence against women has also been conducted in India (Mangoli and Tarase, 2009; Shettar, 2015), and Malysia (Awang and Hariharan, 2011). It cannot be denied, found the news that was marginalized women who become victims of rape. Victims who, in this case, are physically and mentally damaged and must suffer for life, must also be harmed back in public. Sara Mills argues that women tend to be displayed as the wrong and marginalized parties compared to men (Eriyanto, 2009: 199). Women victims of rape are not often used as objects of storytelling. The circumstances of the victims are described by others, not the victims themselves. This allows the victim to become increasingly cornered.

Every daily newspaper has its own way of writing down the news. This is related to the ideology adopted by each daily newspaper. The ideology or idea of a daily newspaper will be a reference for news writers to write the news they get. The news will implicitly show the ideology embraced by 
daily newspapers. Ideology will also show the alignment of news writers to certain parties. Partisanship can be done to women and can also be to men.

In this regard, the ideology to be discussed in this research is gender ideology. Santoso (2011: 41) "The term ideology was first introduced by the French philosopher Destutt de Tracy to explain the science of ideas, a discipline that enables people to recognize their prejudices and biases. Furthermore, Saptiawan (2007: 49) "Ideology is a belief system that people use to explain, explain and justify their behavior and interpret and assess the behavior of others. Furthermore, Darma (2009: 168) asserts that "Gender is a trait inherent in men and women. Gender is a sociocultural construction or social category (femininity and masculinity) reflected in behavior, beliefs and social organization."

Gender ideology relates to the ideas adopted by daily newspapers relating to the regulation of identity, position or position, as well as the behavior of women and men. Any text written by a rape case news author, implicitly demonstrates a certain gender ideology. This gender ideology gives influence to news writers / journalists on how to position victims of rape in the news. The alignment of daily news writers can be known from the tendency of news writers to describe the position of women. The tendency of the alignment of journalists to perpetrators of rape is more often found in news published in the mass media.

In this study, Harian Haluan was chosen as a source of research because one of the reasons that has ever won the national award that is Indonesia Development Goals (MDG) Awards 2012 as a local daily with the highest score as a local daily newspaper in Indonesia who managed to proclaim the facts of development best in terms of quantity and quality with profound and inspiring news. The predicate will affect the way news rape writing is mainly in positioning women, gender ideology and alignment of journalists in the news of rape. Related to this, the purpose of this study is to explain about: (1) the position of female subjects in news of rape and (2) gender ideology and alignment of journalists in the news of rape on the harian Haluan.

\section{Method}

This type of research is qualitative by using Critical Discourse Analysis (AWK). Moleong (2007: 6) asserted that qualitative research is a study that aims to understand the phenomenon of what is experienced by research subjects such as behavior, perception, motivation, action, etc. holistically, and by way of descriptions in the form of words and languages, in a particular, natural context by utilizing various natural methods. That is, this study does not provide treatment of research data. The data data in this study were collected as it is contained in the document of harian Haluan which became the source of data. This research will describe the phenomenon naturally without any engineering.

The method used in this research is Critical Discourse Analysis (AWK) model of Sara Mills. The goal is to make interpretation of the text, especially the news text of rape in the mass media. The language used by a mass media is a reconstruction of journalists. For that reason, through Critical Discourse Analysis (AWK), aka further known the position of female subjects and the linguistic aspect that show the ideology and alignment of journalists in the news of rape on the harian Haluan.

The main instrument of this study is the researchers themselves, using a tool in the form of data collection format. The data collection sheet is a sheet containing the analyzes of the positions of female subjects and ideology as well as the alignment of journalists according to Sara Mills. Researchers as research instruments will collect data by reading steps, inventorying, classifying and interpreting data.

This research data in the form of words, phrases or sentences contained in the daily news rape text of the harian Haluan on the subject-object of women, ideology and alignment of journalists in the 
harian Haluan. The source of this research data is the rape news texts contained in the daily Haluan. The selected news is the January-December 2016 issue.

\section{Results and Discussion}

\section{Women's Position in the News of Rape on Harian Haluan}

The position of women in the news of rape on the harian Haluan tends to be the object (party defined and portrayed by others). Frequency of journalist make woman (victim) as object of storytelling is higher when compared with subject of telling. Based on the data, information is obtained that the news that contains women as the subject (the party that defines / do the story) there is only one news that is news entitled "Wives Asked to Buy Lontong, Ladies Sister Abused" (Haluan, Thursday / April 26, 2017 ). This news is the only news written with information from both parties both victims and suspects. This allows the reader to know the chronology of a rape event from two sides, unlike other news that is only raised through witnesses, the police or suspects.

On the news, the victim made the subject of storytelling. An example of a quote that describes the subject's position in the rape news entitled "The Wives of Lontong Buy Ladong, Ladies Sister Abused" (Haluan, Thursday / April 26, 2017) is as follows. Further information obtained by Haluan, it turns out the koban said, initially had time to resist and fight the action terngska, but the suspect beru $\neg$ paya threaten the victim.

"I was threatened to be killed if I did not obey his will, he replied, if I do not want and report his intentions, he will kill me or my brother," explained the victim "AS" in the room Kanit PPA.

The news writer positions the victim as the subject of the story. This is in accordance with the opinion of Sara Mills (Eriyanto, p. 201) who argued that the subject is the party that defines / do the story. In the above quotation it is known that the victim is directly related to the incident of rape she experienced. This allows the victim to recount the chronology of rape according to his own point of view.

The news writer positions the victim as the subject of the story. This is in accordance with the opinion of Sara Mills (Eriyanto, p. 201) who argued that the subject is the party that defines / do the story. In the above quotation it is known that the victim is directly related to the incident of rape she experienced. This allows the victim to recount the chronology of rape according to his own point of view.

"Soon, he was invited to meet by $\mathrm{R}$ on Tuesday (17/5) then. The victim himself then accepted the suspect's invitation to berte $\neg \mathrm{mu}$ in the area of Seberang Padang. After being invited to meet, the victim was then taken to the residence of $P$ in the area of Simpang Haru ". Arriving there, AAR invited to take pictures and the victim was given a drink of mineral water by $R$ and $P$. Not a long time the victim suffered from dizziness before being raped by these two people. AAR was initially afraid to tell the story to his family, just telling me, because we are so close. He told me that the victim had gotten rough treatment from both perpetrators. This is evident with the victim's blue chest by the perpetrator, "said Leni.

The news writer positions the victim as the object of telling. This is in accordance with the opinion of Sara Mills (in Eriyanto, 2009: 201) who argued that the object is a party defined and portrayed its presence by others. In the above quotation it is known that the victim can not directly tell the story of the rape he experienced. All events are told by others. This makes the victim's position a marginalized party.

Based on this, it is known that the position of women as the most dominant victim in the news of rape on the harian Haluan is the position of the victim as the object of telling. The victim can not 
directly tell the story of the rape she experienced. The incident is told by another party that is news writer / journalist based on witness testimony, the police or even based on the information of the suspect. This of course can be detrimental to the victim because the events told are not necessarily in accordance with the real reality. Such narratives, of course, can harm the victim.

In connection with this, in the news text entitled "Wives Ordered to Buy Lontong, Ladies Sister Behind" there are two positions of victims that is as subject and object of storytelling. On this news, both victims and perpetrators alike are questioned by journalists about the rape chronology. As a result, both parties gave different information. According to the victim, he received threats from the perpetrator and had time to fight. On the contrary, according to the perpetrators of the rape incident occurred without any peralwanan of the victim.

\section{Gender Idea and Alignment of Journalists in the News of Rape on Harian Haluan}

Darma (2013: 175) states that there is a type of gender ideology that regulates the identity of women and men, the position or position of women and men, as well as the behavior of women and men. Gender ideology consists of four types: patriaki ideology, general, familism, motherism, and father-ibuism

Based on the description of the research findings, it is found that the gender ideology contained in the harian Haluan is patriarchy deology. The ideology of patriarchs as proposed by Darma (2013: 175) is an ideology which assumes that men have power over women so that women become an inferior and subordinated party. Examples of news text excerpts containing patriaki ideology are as follows.

"Initially the perpetrator seduced the victim and then tried to feel it, even from the confession of the victim they have made several relationships, "said Kapolresta Padang,

Kombes Pol Chairul Aziz through Kapolsek Koto Tangah, Kompol Jon Hendri who accompanied Kanit Reskrim, AKP M. Nali to Haluan, (30/8/2016)".

The gender ideology contained in the news text is patriarchy ideology. The text indicates a patriarchal form of ideology because it contains male dominance that tends to make women inferior and subordinated. The victim being the described party is incapable of maintaining dignity and selfesteem for allowing himself to be abused by the perpetrator. The text also contains a statement that the victim did not reject when the perpetrator tried to feel it. The word "even" in the text emphasizes that the victim consciously and without the coercion of the perpetrator, commits such immoral acts. This suggests a tendency to elicit stereotypes that the victim is unable to take care of himself so that the victim appears as an inferior party.

Furthermore, regarding the alignment of journalists in the news of rape on the Harian Haluan, journalists tend to side with the perpetrators of rape. Most of the news of rape on Harian Haluan is written by journalists based on information from suspects, police or witnesses. Information from the police also tends to be obtained by journalists from the investigation conducted by the police against the suspect. This of course can be detrimental to the victim because the information obtained may not be in accordance with the events of the natural victim.

The alignment of journalists who tend to favor the perpetrators of rape can be seen in the following excerpt of news texts.

The suspect also implies, for the latter's fornication, he wreaks it out at his home, rather than willing to send the victim to the school of his father-in-law's residence. Even in the midst of the cultivation, he took the victim to his confrontation and re-launched his depraved act. "The latter I was unconscious Bang, that time I had time to take drugs TPA type of pills that I ask from my friend," he explained with a pitiful face.

The alignment of journalists in the excerpt of news texts is marked by the word "pitiful". There are indications that journalists are trying to describe the state of the perpetrator who looks so miserable 
that it needs to be pitied. In fact, journalists could not have written the word. Journalists simply write the utterance delivered by the perpetrator. However, this is a form of alignment of journalists to perpetrators of rape.

The tendency of journalists to side with the perpetrators in the news of rape on Harian Haluan, is proof that women are positioned as often degraded or subordinated. Women who have suffered losses both physically and psychologically, should be re-harmed by the news that degrades the victim's self-esteem. The victim tends to be described as being unable to take good care of himself, too easy to obey a man's invitation and seduction, and unable to keep his dignity by rejecting or resisting when he is sexually abused. Based on these descriptions, it was concluded that the gender ideology that dominates the rape news on the harian Haluan is patriarchal ideology and the alignment of journalists tends to side with the perpetrators of rape.

\section{Conclusions}

Based on research findings and discussion of gender perspectives in news of rape on Haluan two conclusions are described as follows. First, the position of women in the news of rape on the Dominant Haluan is the object of telling. Victims and rape chronology are written by journalists based on information obtained from other parties such as suspects, police or witnesses. The information from the other party tends to make women an inferior or subordinated party. The victim is told as a party who is unable to keep themselves and too easy to follow the will or seduction of the perpetrator. This makes the victim tends to be inferior or inferior. Meanwhile, in cases of rape that the perpetrator is a member of his own family (father or brother-in-law), victims tend to be subordinated. Women are under the authority of men and can not fight because they are under threat or fear.

Secondly, the gender ideology in the news of rape on the Haluan Hour is patriarchal ideology. Most of the news of rape contains the assumption that men have power over women so women tend to be inferior and subordinated. This is similar to the previous description of women's position in the news of rape on Haluan Daily. In connection with this, for the alignment of journalists in the news of rape on Haluan Daily, it was concluded that journalists tend to side with the perpetrators of rape. This is evident from the use of dictionaries and passive sentences in favor of the perpetrator.

\section{References}

Awang and Hariharan. (2011). Determinants of domestic violence: evidence from Malaysia. (Online), Vol. 26., Number 6, (//repository.um.edu.my/7981/1/, accessed 2 January 2018).

Darma, Y.A. (2009). Analisis Wacana Kritis. Bandung: Yrama Widya.

Eriyanto. (2009). Analisis Wacana Pengantar Analisis Teks Media. Yogyakarta: LKis Yogyakarta.

Mangoli dan Tarase. (2009). Crime Against Women in India: A Statistical Review. (Online), Vol.2, No.2, (https://ijcst.journals.yorku.ca/index.php/ijcst/article/view/23401, diakses 2 Januari 2018).

Moleong, L. J. (2005). Metode Penelitian Kualitatif. Bandung: Remaja Rosdakarya.

Santoso, A. (2011). Bahasa Perempuan Sebuah Potret Ideologi Perjuangan. Jakarta: Bumi Aksara.

Saptiawan, S. I. H. (2010). Gender dan Inferioritas Perempuan Praktik Kritik Sastra Feminis. Yogyakarta: Pustaka Belajar.

Shetar, Rajheswari M. (2015). A Study on Issues and Challenges of Women Empowerment in India. (Online), Vol. 17, Issue 4, (http://iosrjournals.org/iosr-jbm/papers/Vol17-issue4/Version-1/B017411319.pdf, diakses 3 Desember 2017). 